\title{
Where Welfare and Criminal Justice Meet: Applying Wacquant to the Experiences of Marginalised Women in Austerity Britain
}

\author{
Larissa Povey \\ Centre for Regional, Economic and Social Research, Sheffield Hallam University \\ E-mail: larissa.j.povey@student.shu.ac.uk
}

Research linking social and penal policy has grown extensively in recent years. Wacquant (2009) suggests that retrenchment of welfare support and expansion of the penal system work together to bear down on marginalised populations in a 'carceral-assistential net'. Empirical and theoretical examinations of these regimes are often underpinned by gendered assumptions. This article addresses this limitation by foregrounding the experiences of women; qualitative interviews offer an insight into their experiences at the intersection of welfare and criminal justice policy in austerity Britain. Their reflections make visible the complex, heterogeneous raft of social assistance, institutional neglect and intensive intervention that characterises women's experiences of the 'carceral-assistential net'. The evidence presented suggests that for marginalised women interventions intensify once behaviour becomes problematic or in times of crisis. While some interventions are valued by those engaged there is little significant impact on their socio-economic position.

Keywords: Welfare, criminal justice, support, punitive, care.

\section{Introduction}

In a climate of hostility towards those in receipt of social assistance, where deprived or vulnerable parents are often met with suspicion, the voices and experiences of women on the receiving end of stigmatising narratives often remain hidden. Wacquant (2009) has conceptualised the relationship between social and penal policy as a 'carceral-assistential net' with which the neoliberal state incapacitates certain marginalised populations. The net comprises a retrenching welfare arm and a growing penal arm, the latter bearing down on the social disorders associated with the erosion of the Keynesian social compact. The criminalising gaze of the centaur-state ${ }^{1}$ is reserved for those at the very bottom of society punitively containing 'two gender sides of the same population coin'; women through 'workfare' and men via 'prisonfare' (Wacquant, 2009). This article draws on new empirical research that explores the lived experiences of women in 'advanced marginality' ${ }^{2}$ and how they negotiate their own position and identity in austerity Britain. In doing so, the article seeks to texture Wacquant's conception ${ }^{3}$ of the 'penal-welfare nexus', with rich accounts of women subject to both arms of the 'carceral-assistential net'.

This article draws on the accounts of eighteen women, twelve of whom have offended and who have been subject to either prison and/or community-based sentences, and six with complex needs who meet the criteria for being 'at risk of offending' (Corston, 2007). All were subject to interventions from agencies across the penal-welfare nexus, the space in which symbiotic welfare and penal policies both punitively contain and support surplus 
populations. Research participants were long-term unemployed and all except one were in receipt of out-of-work benefits.

Following a brief examination of the relevant literature and shifts in UK social policy, the methodological approach and findings of the study are then presented. A key finding is that women at the intersection of the penal-welfare nexus have frequently experienced multiple deprivations, victimhood and institutional neglect in childhood, often linked to subsequent victimisation and criminalisation. Secondly, as adults, child removal proceedings were a significant, highly traumatic feature of some participants' experiences. Finally, participants do not perceive agencies of the criminal justice system, particularly community-based interventions, as carceral. Far from it - they value the therapeutic interventions available, as well as the discretionary protection provided by frontline welfare practitioners from the worst effects of heightened conditionality and punitive sanctions. Although earlier experiences of trauma/intervention may have primed participants cognitively, shaping how they make sense of subsequent and ongoing interventions. Their reflections make visible the complex, heterogeneous raft of social assistance, institutional neglect and intensive interventions which characterise women's experiences of the 'carceral-assistential net'; and spaces where the penal and welfare arms overlap as women cycle through periods of carcerality and assistance. Based on the findings, the concluding section reflects on the extent to which interventions protect women from further exclusion, and the implications this raises for challenging punitive forms of social investment.

\section{Gendering the 'carceral-assistential net'}

Literature examining how UK welfare and penal reforms impact upon women at the intersection of both systems is relatively sparse. ${ }^{4}$ Women in receipt of out-of-work benefits, find themselves subject to high levels of surveillance, moral scrutiny and punishment with highly gendered pathways into the criminal justice system (Bumiller, 2013). Corcoran and Fox $(2012$ : 339-41; 2013) point to a blurring of welfare and penal roles particularly in gender-specific interventions of the 'Diversion Programme' ${ }^{5}$ and more broadly in the 'voluntary sector turn in criminal justice' working partnerships. The Coalition and current Conservative governments' austerity policies have intensified disciplinary welfare linked to behavioural and attitudinal conditions, expanding their reach to groups formerly granted a level of protection in the shift towards 'ubiquitous conditionality' (Dwyer and Wright, 2014: 33). Research suggests that the impact of welfare reform falls disproportionately onto women who rely more on social assistance and who use public services more intensively (Hills, 2014). The concomitant expansion and intensification seen within penal policy criminalises certain families, particularly marginalised, lone female parent households (Ball et al., 2016).

Jensen (2013: 62) emphasises how the continued undermining of social protections 'coalesces more substantively and intensively around the institution of the family and parenting than any other site'. Linked to this has been the successful conflation in public discourse of 'anti-social behaviour' (ASB) and parental deficit, particularly 'dadlessness' (Ashe, 2014: 664). While family intervention may be welcomed in some cases (see Flint, 2012), it is frequently associated with coercion and control (see Gillies, 2012; Crossley, 2016). There is often an adversarial dynamic in parent-state relationships mediated via child protection agencies: parents are expected to 'shape up or the child will be shipped 
out'. A more supportive and compassionate approach would be appropriate, particularly for those living with an accumulation of daily hardships (Featherstone et al., 2014: 9). Child removal is 'doxic' (uncontentious), especially when parents are state outcasts; those multiply deprived and/or who have been through the criminal justice system.

The number of looked after children increased sharply in 2010 and has continued to rise steadily; recurrent proceedings - birth mothers caught in a cycle of repeat pregnancies and removals into care - make up almost a third of care applications (Broadhurst et al., 2015). There are complex reasons behind these developments: long-term variations in social work and legal practice, a number of high profile child deaths and a focus on risk management have influenced the shift towards early intervention (Rogowski, 2013). It is important to place child rescue in a broader historical context of states' managing surplus populations in notably unequal societies, as evidenced by racial assimilation policies and the removal of children from unmarried mothers (Featherstone et al., 2014). Earlier intervention through benefits or cash payments linked to contraception/sterilisation is similarly concerning.

Research, largely from North America, emphasises the link between welfare reform and child protective services involvement (Derr and Taylor, 2004). Swift and Parada (2004) consider child welfare policy as a mechanism for 'policing the poor'. Despite this, little attention has been paid to the experiences of a particular group of 'failed' citizens; mothers who have lost the right to care for their children.

\section{Methods}

The study drawn upon here used a qualitative design; three to four repeat in-depth interviews with eighteen women, aged between eighteen and fifty-six, engaged with services at the nexus of welfare and criminal justice policy. Fifteen women identified as White British, two as BME (black or minority ethnic) and one as Other White. Except one who had been convicted of benefit fraud, all participants were in receipt the Employment and Support Allowance (ESA), with a roughly equal split across those placed in the support group and those in the work-related activity group (WRAG). ESA replaced Incapacity Benefit in 2008 as the main health-related benefit, introducing recurring work capability assessments (WCA) (Grover and Piggott, 2010). Ethical approval for the study was obtained from Sheffield Hallam University. Given the complexities of participants' everyday lives, histories of abuse and trauma, ethical considerations were a chief concern; consent and capacity to give consent were continuously sought/assessed. While the sample size is small and therefore not generalisable to larger populations, the data provide in-depth, contextualised insights into participants' lived experiences of interventions.

Participants were recruited via four gatekeeper organisations in two northern UK cities, two 'women's community centres' (WCC) or 'one-stop-shops', providing services for those 'at risk of (re)offending' and activities attached to community-based sentences; a domestic abuse survivor support group (DASSG) and a homeless project (HP). Attendance at the women's centres often began as a 'specific activity' element of a diversionary/community-based sentence or terms set by probation. Gatekeepers provide therapeutic services as part of gender-specific criminal justice interventions to reduce women's offending and victimisation.

Participants had a range of relationships with the criminal justice system: some had long histories of persistent reoffending, six participants had experienced multiple 
short prison sentences and community-based punishments, others had one conviction or minor offences punished in the community. Of the ten women who had received formal convictions, three participants disclosed child neglect/abuse, arson and being an accessary to murder, the rest disclosed minor offences, more commonly associated with female offending, including possession of a controlled drug, theft or breaching the conditions of a court order or community sentence. Many participants' disclosed poor mental health, histories of drug or alcohol misuse, experiences of domestic violence or sexual victimisation, synonymous with the wider population of female offenders (Prison Reform Trust, 2016).

Gatekeepers comprised statutory, voluntary and private organisations though these distinctions were harder to discern due to the 'hybridisation' of public service providers in the 'mixed economy' of the carceral archipelago (Corcoran and Fox, 2012: 340). Foucault's (1977) term 'carceral archipelago' describes the dispersal of disciplinary mechanisms of social control that permeate societal institutions. Recruitment of participants was mainly through regular attendance of weekly groups at the gatekeeper organisations. Participants were identified by their willingness to take part; a quarter were referred by professionals. The potential for coercion was reduced by ensuring that professionals made clear the voluntary nature of participation and through confidentiality around which referrals engaged fully in the research process. A $£ 15$ 'thank you' shopping voucher was given to each participant. Face-to-face interviews explored dayto-day activities, needs, engagement with services, employment, claimant and offending histories, family, social networks, identities and future aspirations. In addition to qualitative interviews, visual and ethnographic methods were also employed. However, these are not discussed in detail here as the data generated are not relevant to this article. All interviews were digitally recorded, transcribed, coded and analysed for common issues and patterns, the data from which are presented in the next section.

\section{Care, institutional neglect and intensive interventions}

Participants' accounts depict highly traumatic experiences over the life course. ${ }^{6}$ The majority had experienced neglect or abuse during childhood, some had been through the care system, suggesting a 'postcode lottery' of social services intervention (Cafcass, 2014). Many had subsequently experienced abusive relationships as adults; over a third had had children removed from their care; instances of domestic violence, sexual victimisation and exploitation were also prevalent:

My uncle forced me into a lot of things ... I was a working girl ... he used to force me into brothels ... that's how I got in trouble. (Whitney, 26, HP)

I was abused by my dad as a child. So [the counsellor] put me down as having complex post-traumatic stress .... and disassociation disorder. (Lola, 56, WCC)

$[\mathrm{H}]$ e shook me like a rag doll and threw me across the room. (Jessica, 55, DASSG)

A high number of participants (sixteen) had at least one child; of this group seven had experienced the removal of a child or children from their care, two participants had 
experienced the removal of five children from their care, and two participants were going through 'care proceedings' during the research process.

Three are in foster care, my eldest is here in [city] and my other one is with his grandma. (Sally, $36, \mathrm{HP})$

In interviews, it became clear that the loss of children had a profound effect on participants:

That is the worst punishment I've ever had ... if it wasn't for these here [gatekeeper staff] I wouldn't have been able to cope. (Caitlin, 31, WCC)

How am I gonna carry on without my boy, my heart's broke ... I'm not gonna get through it. (Carly, 33, WCC)

Personal experiences of care as children and then the loss of their own children to the care system highlights a cyclical aspect of involvement of social services and the courts. Like those with a criminal record, mothers who have been in care themselves are likely to be 'known' to statutory services and under such scrutiny are more likely to go through the process of having children removed (Broadhurst et al., 2015). Sally and Carly both have five children, none of whom has remained in their care. Social service professionals are perceived as powerful actors whose influence outweighs that of the legal system. Following each removal decision, the plethora of interventions from social and legal agencies halted. They did not receive support to help them become better parents, and be reunited with their children or to prevent the removal of future children: a 'children (but not women) first approach lingers' (Lister, 2006). These experiences are particular to women; on a biological level they directly experience the corporeality of pregnancy and childbirth, furthermore socially constructed ideas on parental identities place different and higher expectations on mothers. The loss of their parenting identity and source of value in society is reflected in their experiences of abandonment.

I think it were when I were fifteen, drinking, drunk and disorderly and going missing from the children's home ... I started with drinking and then ... with drugs ... then my mate were burgling ... that was when the more serious crime started happening ... I was sixteen when I got my independence ... I just got plonked into a bedsit. (Carly, 33, WCC)

Housing some of the most traumatised children, and perennially underinvested in by the state, the ability of children's homes to provide 'effective social investment' and 'human capital' is limited (Churchill, 2011). Sands (2016: 1) suggests that children in care can be fast-tracked towards criminalisation through earlier involvement of criminal justice agencies; 'staff in children's homes ... too frequently [call] ... the police, often over minor incidents'. Clearly, not everyone from a low socio-economic position or who has been in care ends up in the criminal justice system or as a 'failed' parent (Welshman, 2008). However, an examination of participants' life courses highlights the punitive treatment of vulnerable young women, and the subsequent problems they encounter as adults and parents. Participants felt that they had been let down by a state which did 
not protect them, or whose intervention is based on a conflation of 'vulnerability' with 'transgression' (Brown, 2014: 377).

Women engage with services in times of crisis, such as being in conflict with the law or during care proceedings. They receive individualised action plans often comprising services such as counselling or courses to address specific 'vulnerabilities' ranging from budgeting skills to preventing domestic violence victimisation. Periods of intensive, multiagency interventions are perversely interwoven with institutional neglect, ultimately rendering participants socially static. Without addressing underlying structural barriers, those on the margins must better their situations in spite of their disadvantages. The governance of those on the social margins appears highly reactive, a costly and inefficient approach by the state. Interventions on the periphery of the criminal justice system, though perceived as palliative by participants, were ineffective in facilitating the accrual of socio-economic capital. A prominent feature of experiences is the individualisation of responsibility, both as the cause of the negative experiences in their lives (as 'bad' parent or partner) and the cure as the individual is expected to engage and turn their life around.

\section{The 'assistential arm' during times of austerity}

Participants valued engagement with gatekeepers, and on the whole perceived interactions with statutory welfare agencies positively:

She's brilliant my work coach ... the lasses and me was planning on going for a day trip out. And ... I says 'aw I've got a meeting at [Work Programme provider]'. So I went to [my work coach] 'I've got to have this day out'. And she said, 'do you know what ... you just go' ... I've got this banter with her. (Caitlin, 31, WCC)

Superficially, Caitlin's work coach appears to act protectively by letting her miss an appointment. However, also perceptible is coercion evident in her seeking permission and the prioritisation of work coach-guided activities; Caitlin subsequently cancelled a research interview in order to attend a mandatory work-focused interview (WFI). Caitlin accepts that she must perform the behaviours expected of her, signifying an internalisation and normalisation of the disciplinary control exerted by the welfare system.

Whitney and Sally also highlight positive experiences; both are long-term unemployed and have volunteered at the gatekeeper organisation for many years:

They know I am interested in getting back to work, they know I don't want to be on the dole for the rest of my life ... I've never had any problems. (Whitney, 26, HP)

She [the work coach] was lovely. If I didn't make it in, she would ring me up and do the appointment over the phone. I've had crisis loans in the past, I could get them easy. (Sally, 36, $\mathrm{HP})$

These accounts draw attention to positive experiences within the assistential arm of the state. They did not explicitly indicate any dissatisfaction in their interactions with Jobcentre Plus and Work Programme staff or the requirements placed on them. This suggests being placed in the ESA groups provided a modicum of protection from tougher 
conditionality and a sanctions regime. Still, participants performed the requisite attitudes and behaviours, which might be interpreted as a form of 'gaming the system' to ensure benefits are maintained (Batty et al., 2016: 171). Nonetheless, their experiences reflect a 'softness' within the practices of frontline welfare professionals - relationships show understanding and common interests. Grant (2013: 166) found that welfare practitioners 'used their autonomy to make the policy less punitive'; one way of making sense of participant experiences. Carter and Whitworth (2015) show that 'creaming' and 'parking' - where practitioners focus their efforts on those most likely to secure employment remain lingering features of welfare-to-work practice. It seems plausible that participants - being far from the labour market - may have been 'parked'.

There was, however, a strong counter-narrative where participants recounted negative experiences, related to the WCA:

I've had to fight for that [being put in the support group]. I went for medicals ... and they said that I was fit for work. I had to appeal against it and it took fourteen months ... I had to go to court ... nobody believed me ... they said well you don't look as if you've got an illness ... I was on crutches ... And it's like 'well, you can walk with crutches' ... They can just say 'no' ... that's worse [than a sanction] ... My ex-husband did this to me I think he should pay, not the government. (Vivien, 46, DASSG)

Vivien's experience indicates that, although she was initially treated as undeserving, she feels that the state should not be paying for her, despite her disability. During ethnographic fieldwork, I participated in a group session in which participants indicated anxieties around the possibility of failing the WCA and not being able to access ESA.

Despite these instances, participants' experiences are suggestive of a residual assistentia/ welfare arm - though this interpretation should be tempered with a more subtle analysis of participants' compliance with mandated behaviours and attitudes. Participants highlighted the importance of frontline staff in how they perceive the welfare system, with positive accounts linked to interactions with specific individuals acting in discretionary ways to shield them from conditionality and the sanctions regime. The use of discretion by 'street-level bureaucrats' persists in the delivery of employability programmes (Fletcher, 2011: 446). An alternative perspective is that participants deemed the welfare regime less intrusive or punitive than other agencies within the carceral-assistential net, such as social services or the police.

There is a growing body of research that presents nuanced perspectives on the direction of social policy under austerity (Johnsen, and Fitzpatrick, 2010; Flint, 2012). This article contributes to these works through the experiences of women at the penalwelfare nexus who report a paradoxical blend of sanction and support. Participants were often engaged in an 'archipelago of interventions' with multiple providers of 'marginal social welfare' services (Jamieson, 2012). Some participants had been mandated to attend a particular service by a magistrate; others had been signposted by the police or social services. Some had progressed to volunteering and now saw themselves primarily as volunteers, attending daily to 'keep out of trouble'; many enjoyed going to socialise and had gained a sense of belonging. Though service providers were part of, or closely associated with, the criminal justice system, participants did not perceive them as carceral. At a time when social assistance and public services are being cut, these agencies provided essential support and meaningful activity for severely marginalised women. 
While women received services/interventions and out-of-work benefits, if the interventions comprising the 'carceral-assistential net' are to be viewed as remedial, there should be a perceptible 'accumulation of social capital' in ways that support their '(sub)proletarian life strategies' (Wacquant, 2008: 224). Support often focused on empowering women to take control of their lives to 'make change happen', ${ }^{7}$ masking the structural causes of their marginality. The result of this residualised approach is that they remain trapped on the margins despite engaging with multiple services. Interventions have minimal impact, constituting a new form of 'warehousing' taking place in the community rather than the prison (Wacquant, 2010).

These contrasting tones of the penal-welfare experience both support and contradict Wacquant's (2009: 99) notion that 'the state regulates the troublesome behaviours of these women (and their children) through workfare'. The governance of the poor and disorderly is much messier than macro-level conceptions allow. They are undergoing something more complex than penal enlargement and welfare retrenchment. A paradoxical 'archipelago' of interventions jointly 'assistential' and 'carceral', is observable. From this perspective, we are able to gain a more nuanced grasp of the many faces of the neo-liberal state, which may be experienced as supportive, repressive, punitive and protective at the same time.

\section{Discussion and conclusion}

This article textures our understanding of Wacquant's (2009) 'carceral-assistential net' through the experiences of women at the intersection of penal and welfare policy in austerity Britain. The findings suggest that women who have been in the criminal justice system and are far from the labour market derive social protection and support in the 'carceral-assistential net'. Welfare professionals mediate tightening conditions and were perceived positively; participants were not subject to 'workfare', though narratives suggest coercive elements in their relationships with front-line staff. Protection by 'street-level bureaucrats' is a dynamic social settlement, vulnerable to change. Community-based interventions on the periphery of the criminal justice system were experienced as last bastions of support within the carceral-assistential landscape. Participants did not perceive these organisations as carceral or punitive, but as important and meaningful features of their weekly routine. However, it is important to place these cognitive perceptions within the context that shaped them, specifically earlier and on-going instances of trauma and intensive state intervention. In attending sessions and courses, the aim is to empower women to make better choices. While gatekeepers may provide much needed spaces of resistance and relief, they function within the neoliberal apparatus rather than disrupting it and individualise the problems faced by women in positions of advanced marginality.

What is evident is that women at the penal-welfare nexus have often experienced victimhood and institutional neglect earlier in life, and this is regularly linked to their subsequent criminalisation. The penal arm receives them and there is an element of churn between the criminal justice and welfare systems; with some participants remaining warehoused in the 'carceral-assistential net' for many years. The services they received during the research period came as both immediate (in times of crisis) and long-term interventions; social problems are in effect addressed on the periphery of the criminal justice system. 
Child removal proceedings featured significantly in some participants' experiences. These interventions were highly traumatic, and particularly acute when taking place shortly after birth. The basic right to a family and private life was not accessible to these maternal outcasts. Viewed more broadly, these participants lost access to care as 'a resource for citizenship and an expression of citizenship responsibility' (Lister, 2007: 56). The findings of this study uncover a troubling side to social investment and state paternalism. The idealised child is vaunted, mothers must prove their worthiness to parent within a short timescale, which can prove an impossible task for those on a low income experiencing multiple disadvantages. Cyclical experiences of care proceedings will continue to be a feature of women's lives if social policies continue to focus on normative, individualised behaviour change rather than addressing underlying socioeconomic problems faced by families in advanced marginality. An approach that better supports families (particularly mothers) from an earlier stage, before their children's welfare is put at risk and addresses recurrent care proceedings, would provide better life chances for children and marginalised women at the penal-welfare nexus.

Wacquant's ideas provide an important backdrop for this article, which is textured by rich accounts of women's direct experiences of the 'carceral-assistential net'. In doing so, this article brings to the fore the complex, heterogeneous raft of social assistance, institutional neglect (up to the point of problematic behaviour), punishment and intensive interventions that women in advanced marginality experience at the micro-level. The article also highlights the gendered character of social welfare and disciplining. Genderspecific criminal justice policies aim to divert women from custody and provide support to address their specific vulnerabilities and prevent further criminalisation. This approach, while palliative, fails to significantly change the socio-economic position of participants and comes only once they are at risk of offending.

\section{Acknowledgements}

I am grateful to the women who took part in this study whose experiences are reported here. I would also like to thank Del Roy Fletcher, Tony Gore, Richard Crisp, Ian Cole, Kesia Reeve, and Elaine Batty for their comments on earlier drafts. I am also indebted to the guest editors of this special issue for their guidance, and to the two anonymous peer reviewers for their thoughtful comments.

\footnotetext{
Notes

1 'liberal at the top and paternalistic at the bottom' (Wacquant, 2009: 312).

2 At the extremes of social and economic exclusion.

3 Which focuses principally on the US context.

4 See Stewart and Gobeil (2015) and Martin and Wilcox (2012).

5 Diverting women from custody became a priority following the Corston (2007) report.

6 Pseudonyms are used throughout.

7 Title of a course participants completed.
}

\section{References}

Ashe, F. (2014) '“All about Eve": mothers, masculinities and the 2011 UK riots', Political Studies, 62, 652-68. 
Ball, E., Batty, E. and Flint, J. (2016) 'Intensive family intervention and the problem figuration of "troubled families"', Social Policy and Society, 15, 263-74.

Batty, E., Fletcher, D., Flint, J. and McNeill, J. (2016) 'Gamers or victims of the system? Welfare reform, cynical manipulation and vulnerability', The Journal of Poverty and Social Justice, 15, 171-85.

Broadhurst, K., Shaw, M., Kershaw, S., Harwin, J., Alrouh, B., Mason, C. and Pilling, M. (2015) 'Vulnerable birth mothers and repeat losses of infants to public care: is targeted reproductive health care ethically defensible?', Journal of Social Welfare and Family Law, 37, 1, 84-98.

Brown, K. (2014) 'Questioning the vulnerability zeitgeist: care and control practices with "vulnerable" young people', Social Policy and Society, 13, 3, 371-87.

Bumiller, K. (2013) 'Incarceration, welfare state and labour market nexus', in B. Carlton and M. Segrave (eds.), Women Exiting Prison: Critical Essays on Gender, Post-Release Support and Survival, Abingdon, Oxon: Routledge, 13-33.

Cafcass (2014) 'Cafcass operating Framework', https://www.cafcass.gov.uk/media/212819/cafcass_ operating_framework.pdf [accessed 17.05.2016].

Carter, E. and Whitworth, A. (2015) 'Creaming and parking in quasi-marketised welfare-to-work schemes: designed out of or designed in to the UK work programme?', Journal of Social Policy, 44, 2, 277-96.

Churchill, H. (2011) 'Wither the social investment state? Early intervention, prevention and children's services reform in the new policy context', Paper presented at the Social Policy Association International conference Bigger Societies, Smaller Governments? University of Lincoln, 4-6 July 2011.

Corcoran, M. and Fox, C. (2012) 'A seamless partnership? Developing mixed economy interventions in a non-custodial project for women', Criminology and Criminal Justice, 13, 3, 336-53.

Corston, J. (2007) The Corston Report: A Review of Women with Particular Vulnerabilities in the Criminal Justice System, London: Home Office.

Crossley, S. (2016) 'The Troubled Families Programme: in, for and against the state?', Social Policy Review: Analysis and Debate in Social Policy, 28, 127.

Derr, M. K. and Taylor, M. J. (2004) 'The link between childhood and adult abuse among long-term welfare recipients', Children and Youth Services Review, 26, 2, 173-84.

Dwyer, P. and Wright, S. (2014) 'Universal Credit, ubiquitous conditionality and its implications for social citizenship', The Journal of Poverty and Social Justice, 22, 1, 27-35.

Featherstone, B., Morris, K. and White, S. (2014) Re-imagining Child Protection: Towards Humane Social Work with Families, Bristol: Policy Press.

Fletcher, D. R. (2011) 'Welfare reform, Jobcentre Plus and the street-level bureaucracy: towards inconsistent and discriminatory welfare for severely disadvantaged groups?', Social Policy and Society, 10, 4, 44558.

Flint, J. (2012) 'The inspection house and neglected dynamics of governance: the case of domestic visits in family intervention projects', Housing Studies, 27, 6, 822-38.

Foucault, M. (1977) Discipline and Punish: The Birth of the Prison, London: Penguin Books.

Gillies, V. (2012) 'Family policy and the politics of parenting: from function to competence', The Politicization of Parenthood, 5, 13-26.

Grant, A. (2013) 'Welfare reform, increased conditionality and discretion: Jobcentre Plus advisers' experiences of targets and sanctions', Journal of Poverty and Social Justice, 21, 2, 165-76.

Grover, C. and Piggott, L. (2010) 'From incapacity benefit to employment and support allowance: social sorting, sickness and impairment, and social security', Policy Studies, 31, 2, 265-82.

Hills, J. (2014) Good Times Bad Times: The Welfare Myth of Them and Us, Bristol: Policy Press.

Jamieson, R. (2012) 'The archipelago of intervention: governing the awkward citizen', Doctoral thesis, Durham University.

Jensen, T. (2013) 'Austerity parenting', Soundings: A Journal of Politics and Culture, 55, 1, 60-70.

Johnsen, S. and Fitzpatrick, S. (2010) 'Revanchist sanitisation or coercive care? The use of enforcement to combat begging, street drinking and rough sleeping in England', Urban Studies, 47, 8, 1703-23. 
Lister, R. (2006) 'Children (but not women) first: New Labour, child welfare and gender', Critical Social Policy, 26, 2, 315-35.

Lister, R. (2007) 'Inclusive citizenship: realizing the potential', Citizenship Studies, 11, 1, 49-61.

Martin, D. and Wilcox, P. (2012) 'Women, welfare and the carceral state', in P. Squires and J. Lea (eds.), Criminalisation and Advanced Marginality: Critically Exploring the Work of Loic Wacquant, Bristol: The Policy Press, 151-71.

Prison Reform Trust (2016) 'Prison: the facts', http://www.prisonreformtrust.org.uk/Portals/0/Documents/ Bromley\%20Briefings/Summer\%202016\%20briefing.pdf [accessed 18.11.2016].

Rogowski, S. (2013) Critical Social Work with Children and Families: Theory, Context and Practice, Bristol: Policy Press.

Sands, C. (2016) Criminal Care, http://howardleague.org/wp-content/uploads/2016/02/Criminal-Care.pdf [accessed 11.05.2016].

Stewart, L. and Gobeil, R. (2015) 'Effective interventions for women offenders: a rapid evidence assessment', National Offender Management Service Analytical Summary, London: Ministry of Justice

Swift, K. J. and Parada, H. (2004) 'Child welfare reform: protecting children or policing the poor?', Journal of Law and Social Policy, 19, 1.

Wacquant, L. (2008) 'Ordering Insecurity', Radical Philosophy Review, 11, 1, 1-19.

Wacquant, L. (2009) Punishing the Poor: The Neoliberal Government of Social Insecurity, Durham, NC: Duke University Press.

Wacquant, L. (2010) 'Crafting the neoliberal state: workfare, prisonfare, and social insecurity', Sociological Forum, 25, 2, 197-220.

Welshman, J. (2008) 'The cycle of deprivation: myths and misconceptions', Children and Society, 22, 2, 75-85. 